\title{
3 Tesla is the preferred field strength for perfusion imaging in coronary artery disease - a comparison to 1.5 Tesla and fractional flow reserve
}

\author{
P Bernhardt ${ }^{*}, T$ Walcher, D Buckert, W Rottbauer, V Rasche \\ From 16th Annual SCMR Scientific Sessions \\ San Francisco, CA, USA. 31 January - 3 February 2013
}

\section{Background}

Adenosine perfusion imaging at 1.5 Tesla $(\mathrm{T})$ has been shown to yield good diagnostic values in comparison to quantitative coronary angiography. Perfusion imaging at 3 $\mathrm{T}$ has the potential benefit of higher contrast- and signalto-noise ratios. However, little is known about diagnostic performance of $3 \mathrm{~T}$ perfusion imaging in comparison to $1.5 \mathrm{~T}$ and in comparison to invasive measurement of fractional flow reserve (FFR). We sought to evaluate visual and quantitative assessment of adenosine perfusion at $3 \mathrm{~T}$ in comparison to $1.5 \mathrm{~T}$ and to coronary angiography in patients presenting with suspected coronary artery disease (CAD).

\section{Methods}

86 consecutive patients with suspected CAD were enrolled in this study. All patients underwent adenosine perfusion at $3 \mathrm{~T}$ (Achieva, Philips Medical Systems) and $1.5 \mathrm{~T}$ (Intera, Philips Medical Systems) within 72 hours with subsequent coronary angiography within 72 hours. Two independent patient groups were formed. In group $11(\mathrm{~N}=52)$ quantitative coronary analysis (QCA) was compared to qualitative perfusion MRI imaging. Group $2(\mathrm{~N}=34)$ underwent FFR measurement in all three major coronary arteries in comparison to quantitative myocardial perfusion reserve (MPR).

\section{Results}

In both groups a significant $(\mathrm{p}<0.05)$ higher sensitivity and specificity (group 1: 0.88 vs 0.80 and 0.96 vs. 0.89 ,

University of Ulm, Ulm, Germany

(c) 2013 Bernhardt et al; licensee BioMed Central Ltd. This is an Open Access article distributed under the terms of the Creative Commons Attribution License (http://creativecommons.org/licenses/by/2.0), which permits unrestricted use, distribution, and $\mathrm{p}<0.01$; group 20.91 vs. 0.62 and 1.0 vs. $0.77, \mathrm{p}<0.001$ ) was found for $3 \mathrm{~T}$ when compared to $1.5 \mathrm{~T}$.

\section{Conclusions}

$3 \mathrm{~T}$ appears to be the superior field strength for visual or quantitative analysis of myocardial perfusion in CAD as shown in our two consecutive patient groups.

Published: 30 January 2013

doi:10.1186/1532-429X-15-S1-W4

Cite this article as: Bernhardt et al:: 3 Tesla is the preferred field

strength for perfusion imaging in coronary artery disease - a

comparison to 1.5 Tesla and fractional flow reserve. Journal of

Cardiovascular Magnetic Resonance 2013 15(Suppl 1):W4.

Submit your next manuscript to BioMed Central and take full advantage of:

- Convenient online submission

- Thorough peer review

- No space constraints or color figure charges

- Immediate publication on acceptance

- Inclusion in PubMed, CAS, Scopus and Google Scholar

- Research which is freely available for redistribution

\section{: 101 Len Central Commons Attribution License (http://creativecommons.org/licenses/by/2.0),}

